\title{
Durable bonds at the adhesive/dentin interface: an impossible mission or simply a moving target?
}

\section{Durabilidade da adesão na interface adesivo/dentina: uma missão impossível ou simplesmente um alvo em movimento?}

\section{Paulette SPENCER}

Department of Mechanical Engineering - Bioengineering Research Center - University of Kansas - Lawrence - KS.

\section{Qiang YE}

\section{Jonggu PARK}

Bioengineering Research Center - University of Kansas - Lawrence - KS.

\section{Anil MISRA}

Bioengineering Research Center - Department of Civil Engineering - University of Kansas - Lawrence - KS.

\section{Brenda S. BOHATY}

Department of Pediatric Dentistry - University of Missouri - Kansas City - School of Dentistry - Kansas City - MO.

\section{Viraj SINGH}

Department of Mechanical Engineering - Bioengineering Research Center - University of Kansas - Lawrence - KS.

\section{Ranga PARTHASARATHY}

Bioengineering Research Center - University of Kansas - Lawrence - KS.

\section{Fábio SENE}

Department of Restorative Dentistry - State University of Londrina - School of Dentistry - Londrina - Brazil.

\section{Sérgio Eduardo de Paiva GONÇALVES}

Department of Restorative Dentistry - School of Dentistry of São José dos Campos - UNESP - Univ Estadual Paulista - São José dos Campos - SP - Brazil.

\section{Jennifer LAURENCE}

Department of Pharmaceutical Chemistry - University of Kansas - Lawrence - KS.

\begin{abstract}
Composite restorations have higher failure rates, more recurrent caries and increased frequency of replacement as compared to dental amalgam. Penetration of bacterial enzymes, oral fluids, and bacteria into the crevices between the tooth and composite undermines the restoration and leads to recurrent decay and failure. The gingival margin of composite restora tions is particularly vulnerable to decay and at this margin, the adhesive and its seal to dentin provides the primary barrier between the prepared tooth and the environment. The intent of this article is to examine physico-chemical factors that affect the integrity and durability of the adhesive/dentin interfacial bond; and to explore how these factors act synergistically with mechanical forces to undermine the composite restoration. The article will examine the various avenues that have been pursued to address these problems and it will explore how alterations in material chemistry could address the detrimental impact of physico-chemical stresses on the bond formed at the adhesive/dentin interface.
\end{abstract}

\section{KEYWORDS}




\section{INTRODUCTION}

\section{Clinical Performance: Composite versus Dental Amalgam Restorations}

In 2005, 166 million dental restorations were placed in the United States [1] and clinical studies suggest that more than half were replacements for failed restorations. [2] Replacement of failed restorations accounts for nearly $70 \%$ of all restorative dentistry [2] and the emphasis on replacement therapy is expected to increase as concern about mercury release from dental amalgam forces dentists to select alternative materials. The use of dental amalgam is being discontinued in response to global concerns about mercury in the environment. Dental amalgam is identified as one of the top five mercury-added products; it is rated \#5 behind batteries, measuring devices, electric switches and relays, and mercurycontaining light bulbs. [3] The most common alternative to dental amalgam is resin composite [4] but composite restorations have higher failure rates, more recurrent caries and increased frequency of replacement [2, 4-10].

In 2009, based on the review of dental records from 3,071 patients, Simecek and colleagues reported a significantly higher risk of replacement for posterior composite restorations as compared to amalgam [4]. In a study of amalgam and composite restorations placed by 243 Norwegian dentists, the mean age of failed amalgam was $\sim 11$ years while the mean age for failed composite was statistically significantly lower at 6 years. [8] The need for additional treatment was 50\% greater in children receiving composite restorations as compared to children treated with dental amalgam [11] After nearly 4 decades of research the clinical lifetime of large to moderate posterior composite restorations continues to be approximately one-half that of dental amalgam [12].

The reduced clinical lifetime of moderate to large class II composite restorations can be particularly detrimental for our patients because removal of these restorations can lead to extensive loss of sound tooth structure. For example, the removal of composite restorations produced significantly greater increases in cavity volume in comparison to the removal of amalgam [13]. The increase in cavity volume and increased frequency of replacement means that significantly greater amounts of sound tooth structure will be lost with treatment and re-treatment of class II composite restorations [13]. Over the lifetime of the patient, the additional loss of tooth structure will translate to more complex restorations and eventually total tooth loss. The reduced longevity, increased frequency of replacement and the need for a more complex restoration means increased costs to the patient in terms of both time and money [14].

\section{Composite Restoration Failure}

The primary factor in the clinical failure of moderate to large composite restorations is secondary decay at the margins of the restorations [8]. As an example, in a study of radiographs from 459 adults, age 18-19 years, the investigators reported that among 650 interproximal restorations the failure rate as a result of secondary or recurrent decay was $43 \%$ for composite as compared to $8 \%$ for amalgam [7]. In a separate study of amalgam and composite restorations placed in 8-12 year old children, the primary reason for failure of both materials was secondary decay, but secondary decay was 3.5 times higher in composite restorations [5].

The development of secondary decay indicates that the seal at the composite/tooth interface is not resistant to the physical, chemical, and mechanical stresses that are present in the mouth (Figure 1). Indeed, the clinical failure of moderate to large composite restorations has been linked to a breakdown of the bond at the tooth surface/composite material interface [12,15-20] and increased levels of the cariogenic bacteria, Streptococcus mutans, at the perimeter of these materials [21-25]. The breakdown of the composite/tooth bond has been attributed to the failure of our current adhesives to consistently seal and adhere to the dentin [2,20-29]. Results from both in vitro and in vivo studies indicate that failure of the adhesive/dentin $(\mathrm{a} / \mathrm{d})$ bond allows bacterial enzymes, oral fluids, and even bacteria to infiltrate the spaces between the tooth and composite [30] (Figure 2). The penetration of these agents into the spaces between the tooth and composite undermines the restoration and leads to recurrent caries, hypersensitivity, and pulpal inflammation $[2,20,26,31,32]$.

Clinical studies report poor marginal adaptation, marginal discoloration, and loss of retention of the composite restoration when the a/d interface is exposed to the oral cavity 33. Acid-etching provides effective mechanical bonding between the composite restoration and treated enamel, but breakdown at the dentin surface continues to threaten the long-term viability of moderate to large posterior composite restorations [18,20,22,31,34,35]. 

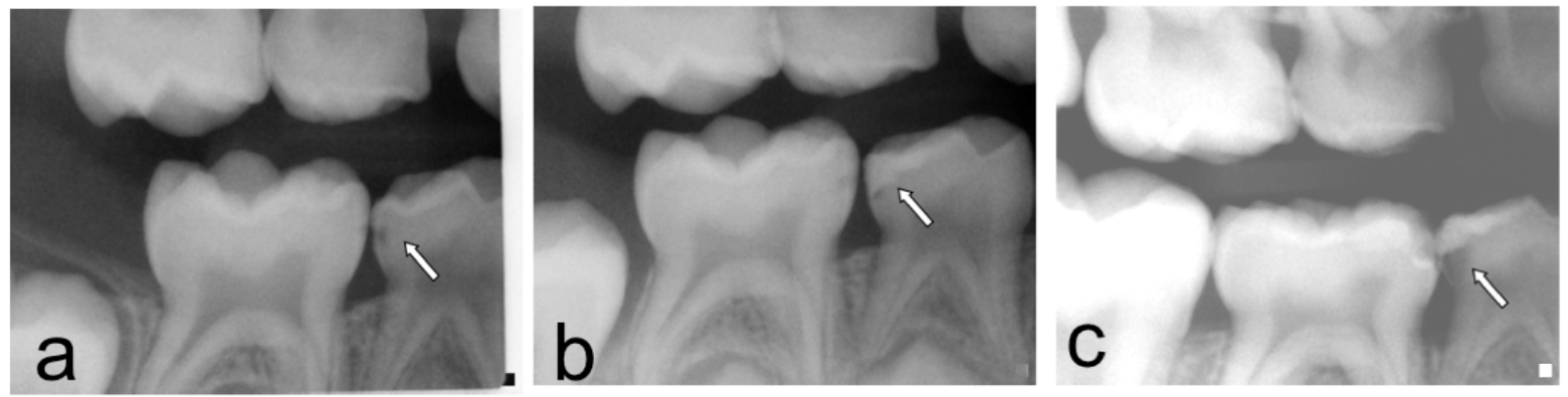

Figure 1 - Radiographic image of primary teeth on right side. a) The arrow denotes carious lesion on the proximal surface of mandibular right first primary molar. b) The arrow denotes the composite restoration on first primary molar. c) Radiographic image of primary teeth on right side, 2 years after figure 1b. The arrow denotes the failed class II composite restoration because of extensive decay.

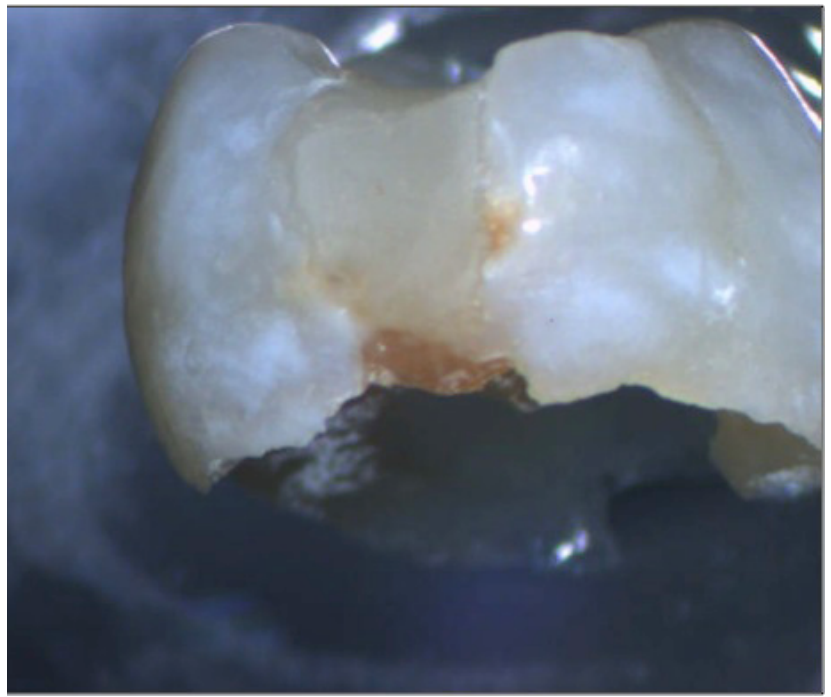

Figure 2 - Primary molar restored with posterior composite. Note staining at gingival margin indicating recurrent decay. Tooth was collected through protocol approved by the appropriate health sciences institutional review board.

Under clinical conditions, one can frequently detect a separation between the composite material and the tooth surface at the gingival margin [34]. Clinicians frequently find very little enamel available for bonding at the gingival margin of class II composite restorations and thus, the bond at this margin depends on the integrity of the seal formed with dentin. The gaps at the gingival margin of class II composite restorations (Figure 3 ) have been related to very technique sensitive and unreliable dentin bonding [34,36].

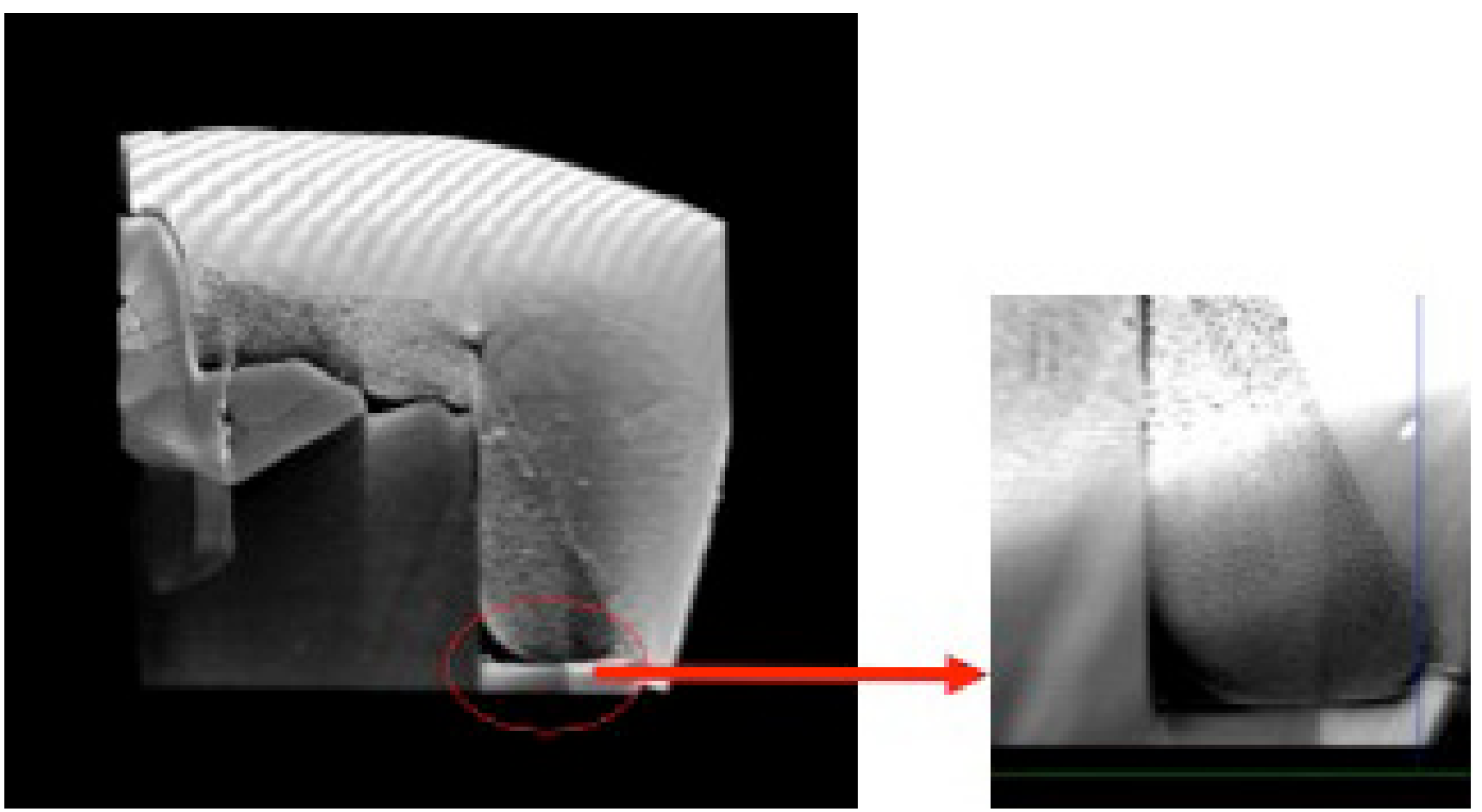

Figure 3 - X-ray micro-CT image of molar restored with composite restoration. Note dark region in proximity of gingival margin suggesting gap formation. 
The gingival margin in class II composite restorations is the most common location of bonding failures [37]. Purk and colleagues [38] compared the microtensile dentin bond strength of gingival and proximal cavity walls of class II restorations. Their results showed that the dentin adhesive bond of composites to gingival walls was significantly weaker, and thus, at increased risk of failure compared to the bond to proximal walls.

Spectroscopic results from a separate study indicated a twofold difference in the depth of dentin demineralization at the gingival and proximal margins [29]. The differences in demineralization depth may be due to less mineralized dentin at the gingival margin. For example, the mineral/matrix ratio in dentin at the gingival margin was less than half the ratio at the proximal wall. Less mineral and increased density and size of the tubules [39] translate to faster and deeper etching at the gingival margin as compared to the proximal wall.

Although dentin etching was deeper, there was considerably less adhesive penetration at the gingival margin as compared to the proximal wall [29]. This discrepancy between etching depth and adhesive penetration led to a large area of exposed collagen at the gingival margin. It was suggested previously that adhesives could infiltrate dentin at the gingival margin more efficiently because of the increased number of tubules per unit area [40]. However, water content is higher in dentin at the gingival margin. This is not only because of the water already present within the demineralized dentin matrix, but also because patent tubules contribute to the contamination of the prepared surface with a great amount of dentinal fluid [41]. The cumulative effect of the increased water leads to reduced adhesive infiltration and lower monomer/ polymer conversion of the adhesive at the gingival margin as compared to the proximal wall [29]. Under in vitro conditions, adhesive monomers or oligomers and unprotected collagen at the gingival margin of Class II composite restorations undergo hydrolytic degradation after 90-days aqueous storage [28].

\section{Dentin Bonding \& the Hybrid Layer}

Based on numerous morphologic investigations and bond strength studies [42-46] it is generally accepted that the primary factors critical in determining an adequate $\mathrm{a} / \mathrm{d}$ bond are: wetting of the dentin substrate by components of the adhesive system [42,47] and micromechanical interlocking via resin penetration and entanglement of exposed collagen fibrils in the demineralized dentin [48-50]. Morphologic evidence of resin penetration of the exposed collagen fibrils was first reported by Nakabayashi [51] and he called the distinct zone between the bulk adhesive and the non-demineralized dentin the 'hybrid layer'. Current adhesive systems that acid etch the dentin characteristically bond via hybridization [52].

The hybrid layer is formed when an adhesive resin penetrates a demineralized or acid-etched dentin surface and infiltrates the exposed collagen fibrils. During acid etching, the mineral phase is extracted from a zone that measures between 1 and $\sim 10 \mu \mathrm{m}$ of the dentin surface [53-55]. The composition of the exposed substrate differs radically from mineralized dentin. For example, mineralized dentin is $50 \%$ mineral, $30 \%$ collagen, and $20 \%$ water by volume [56], whereas demineralized dentin is $30 \%$ collagen and $70 \%$ water [53-57]. With removal of the mineral phase, the collagen fibers are suspended in water. If there is a substantial zone of demineralization and the water supporting the collagen network is removed either by air drying or the action of an air syringe the collagen will collapse [57-59]. A collapsed collagen network reduces the porosity and inhibits resin penetration through the demineralized layer[57]. It forms a barrier between the demineralized layer and the underlying intact or unreacted dentin surface $[46,59,60]$. A collapsed collagen network compromises the a/d bond $[46,53,58,59]$ as well as the marginal integrity of the composite restoration.

\section{III.A. Wet bonding}

In the early $1990 \mathrm{~s}$, wet bonding was introduced to counteract the problems of collagen collapse $[48,61$ 64]. Wet bonding means that the dentin is kept fully hydrated throughout the bonding procedure; the surface morphology of the demineralized layer does not change because the water supporting the collagen matrix is not removed [65]. Bond strength results [48,61-64] with "wet" bonding support these findings, that is, the higher bond strengths with this technique reflect the minimal collapse of "wet" versus air-dried dentin collagen[57]. It is speculated that moist dentin provides a more porous collagen network and that increased porosity means more space for adhesive infiltration[43,46,57,61-63].

With wet bonding techniques, the channels between the demineralized dentin collagen fibrils are filled with water, solvent, conditioner, and/or oral fluids $[57,66]$. The only mechanism available for adhesive resin infiltration is diffusion of the resin 
into whatever fluid is in the spaces of the substrate and along the collagen fibrils. Ideally, the solvent in combination with hydrophilic monomers, (e.g. hydroxyethyl methacrylate (HEMA)) conditions the collagen to remain expanded during adhesive infiltration. However, HEMA, a primary component in many single bottle commercial dentin adhesives, can dramatically reduce the evaporation of water[67]. The addition of HEMA reduces the mole fraction of water and therefore reduces the partial pressure of water (Dalton's law of partial pressures). As the partial pressure of water drops it becomes more and more difficult to remove residual water from the demineralized dentin matrix. Hydrophobic monomers, such as 2,2-bis[4(2-hydroxy-3-methacryloyloxypropyloxy)-phenyl] propane (BisGMA), would resist diffusing into these sites where there is residual water[50,68,69].

Under in vivo conditions, there is little control over the amount of water left on the tooth. As a result, it is possible to leave the dentin surface so wet that the adhesive actually undergoes physical separation into hydrophobic and hydrophilic-rich phases [68]. Results from our laboratory indicated that excess moisture prohibited the formation of an impervious, structurally integrated $\mathrm{a} / \mathrm{d}$ bond at the gingival margin of Class II composite restorations[28,29]. Clinicians must routinely attempt to bond to naturally wet substrates such as caries-affected dentin [70] or deep dentin[71-74]. The water content of caries-affected dentin has been reported to be 2.7 times greater than that of normal dentin[70]. In deep dentin, $22 \%$ of the surface area is exposed tubules while exposed tubules account for $1 \%$ of the surface area of dentin close to the DEJ[75]. The large increase in surface area attributable to tubules means that in deep dentin, pulpal fluid will contribute additional moisture to that already present within the demineralized dentin matrix. Since our current adhesives are very sensitive to excess moisture, bonding to these clinically relevant substrates is a formidable challenge[74,76-78].

\section{III.B. Sensitivity of adhesive to wet bonding conditions}

The sensitivity of our current adhesives to excess moisture is reflected in the water-blisters that form in adhesives placed on over-wet surfaces [79-81] and adhesive phase separation that leads to very limited infiltration of the critical dimethacrylate component $[50,68,82]$. The optimum amount of wetness varies as a function of the adhesive system [83]. Additionally, it is impossible to simultaneously achieve uniform wetness on all of the walls of the cavity preparation [84]. Wet bonding is, in short, a very techniquesensitive procedure and optimum bonding with our current commercial adhesives occurs over a very narrow range of conditions, e.g. water content [73].

One suggested approach to these problems is "ethanol-wet bonding" [33,85]. A concern with this method is that in the clinical setting this solvent may be diluted because of repeated exposure of the material to the atmosphere or concentrated because of separation of the bonding liquids into layers within the bottle. Results from our lab have shown an inverse relationship between mechanical and thermal properties and the concentration of ethanol that is present during photo-polymerization of model BisGMA-based adhesives [86]. In addition, the hybridization process is very sensitive to the ethanol content in the adhesive system [78]. Although the effect of "ethanol-wet bonding" on durability is not known, results from our lab suggest that this approach will not overcome the clinical challenges associated with $\mathrm{a} / \mathrm{d}$ bonding.

Current strategies to promote bonding of the resinous materials to intrinsically wet substrates also include the incorporation of ionic and hydrophilic monomers into the adhesive [87]. These adhesives etch and prime simultaneously, thus addressing the problems of collagen collapse and simplifying the bonding protocol. Unfortunately, the hydrophilic nature of these components enhances water sorption and hydrolytic breakdown in the mouth [84,8790]. With these systems, the bonded interface lacks a nonsolvated hydrophobic resin coating and thus, the resultant hybrid layers behave as semipermeable membranes permitting water movement throughout the bonded interface even after adhesive polymerization [33]. The higher concentration of hydrophilic monomers in these systems is associated with decreased structural integrity at the a/d interface [33,91]. In vivo aging studies have reported degradation of the a/d bond at 1 -year even when the bonded dentin was protected by enamel from direct exposure to the oral environment [92]. These results suggest that hydrophilicity and hydrolytic stability of resin monomers are generally antagonistic [84].

\section{IDEAL HYBRID LAYER}

It is generally accepted that the fundamental processes involved in bonding an etch-and-rinse adhesive to dentin are: removal of the mineral phase 
from the dentin without altering the collagen matrix and filling the voids left by the mineral with adhesive that undergoes complete in situ polymerization. Ideally, the resultant resin-reinforced or hybrid layer would be a 3-dimensional polymer/collagen network that would provide both a continuous and stable link between the bulk adhesive and dentin substrate. There is substantial evidence to suggest that this ideal objective is not achieved. [28,49,50,69,77,82,93-97] Instead of serving as a stable connection between the bulk adhesive and subjacent intact dentin, the hybrid layer has been called the weakest link in the adhesive/ dentin $(\mathrm{a} / \mathrm{d})$ bond [98].

\section{IV.A. Degradation of the hybrid layer}

Degradation of the hybrid layer could be broadly divided into 2 major categories: hydrolytic degradation of the collagen matrix and hydrolytic degradation of the adhesive within the hybrid layer. [99] It has been hypothesized that the in vivo degradation of the hybrid layer follows a cascade of events that begins when the dentin is acid-etched. [100,101] Disruption of the tooth structure by acid-etching exposes and activates proteolytic enzymes, e.g. matrix metalloproteinases (MMPs) which can degrade the exposed collagen component of the hybrid layer. [102,103] Degradation of the hybrid layer by MMPs is expected to be most important acutely in the period following adhesive application.

Investigators have sought to address the impact of MMPs using techniques that would remineralize the collagen that is not infiltrated by adhesive. [104]While remineralizing the exposed collagen within the hybrid layer is interesting, other investigators have reported that an adhesive that replaces the spaces occupied by free and loosely bound water within the exposed collagen (demineralized dentin matrix) inhibits MMP activity. [105,106] Cationic quaternary ammonium methacrylates also inhibit MMP activity.[107]

Chronic deterioration of the hybrid layer involves hydrolysis and leaching of the adhesive that has infiltrated the collagen (demineralized dentin matrix). $[50,69,99,108,109]$ Leaching is facilitated by water ingress into the loosely cross-linked or hydrophilic domains of the adhesive. The hydrophilic domain exhibits limited monomer/polymer conversion because of adhesive phase separation [68] and lack of compatibility between the hydrophobic photoinitiator and hydrophilic phase. [110,112]The poorly polymerized hydrophilic phase degrades rapidly in the aqueous environment. Resin elution continues to occur through the nanoleakage channels; water movement along the length and breadth of the hybrid layer becomes more rapid as transport pathways form relatively large water-filled channels. [33,83,113] The previously resin-infiltrated collagen matrix is exposed and vulnerable to attack by proteolytic enzymes[114,115].

The structure of methacrylate adhesives suggests a general mechanism for their chemical and enzymatic degradation in the mouth. On prolonged exposure of the restoration to oral fluids water begins to penetrate the resin. Water initially enters the matrix by diffusion into loosely cross-linked or hydrophilic domains or may be trapped within the matrix during photopolymerization. $[70,116]$ Portions of the matrix may be directly exposed to oral fluids, particularly at the gingival margin of Class II and V composite restorations. Mechanical wear of the exposed adhesive may further accelerate matrix degradation by abrading the surface, increasing the surface area and allowing greater ingress of both water and enzymes. The presence of water promotes the chemical hydrolysis of ester bonds in methacrylate materials. This reaction is expected to be relatively slow at the neutral $\mathrm{pH}$ typical of saliva, but excursions in $\mathrm{pH}$ caused by foods or cariogenic bacteria may lead to transient acid or base catalysis. The carboxylate and alcohol degradation products of ester hydrolysis are more hydrophilic than the parent ester, further enhancing the local ingress of water. Over years of exposure to salivary fluids, local domains of the methacrylate network may become sufficiently degraded and/or hydrophilic to permit access by esterases, which greatly accelerate ester bond hydrolysis.

Human saliva contains a variety of enzymes which may participate in the degradation of the adhesive as well as the composite $[89,92,117-121]$. The susceptibility of acrylate dental materials to degradation by esterases is well established [119,122-126]. The esterase-catalyzed degradation of monomethacrylates, dimethacrylates and commercial dental resins has been documented in solution $[122-124,126]$, in saliva samples $[124,125,127]$, and in vivo [92]. In vitro studies have typically used one or more of the following esterases: cholesterol esterase (CE; EC 3.1.1.13) $[122,124,126]$ acetylcholinesterase (ACHE; EC 3.1.1.7) $[122,126]$ and pseudocholinesterase (PCE, aka butyrylcholinesterase; EC 3.1.1.8) [122,124,126]. Human saliva samples have been shown to contain CE and PCE activity in sufficient quantity to degrade composite resins $[124,128]$. In vitro degradation of dimethacrylates (BisGMA, TEGDMA) in the presence of $\mathrm{PCE}$ and $\mathrm{CE}$ was reduced by a specific esterase inhibitor, phenylmethylsulfonyl fluoride [124], supporting an 
esterase-catalyzed mechanism of degradation. Esterases in solution and in saliva catalyze the hydrolysis of both soluble methacrylate monomers and polymer particulates $[125,126]$, suggesting that solid dental restorations are directly susceptible to esterase attack. Monomers and polymers of the monomethacrylates (e.g., HEMA) have been shown to be more resistant to esterase digestion (by ACHE, CHE) than the dimethacrylates [126]. CE and PCE have been shown to act synergistically in degrading dimethacrylates (BisGMA, TEGDMA) in vitro [122]. A modified dimethacrylate containing urethane segments (urethane-modified BisGMA) showed up to an 86-fold reduction in CE-catalyzed degradation relative to the unmodified control (BisGMA) [123]. This enhanced esterase resistance was attributed to the chemistry of the modified dimethacrylate, particularly the greater hydrophobicity and hydrogen-bonding capability of the urethane segments [123]. Dimethacrylates containing aromatic functional groups or branched methacrylate linkages have also shown greater esterase resistance [126].

Although many factors may contribute to the breakdown of methacrylate adhesives, their chemical "Achilles heel" may be the ester linkages. Indeed, the breaking of covalent bonds within the polymer by addition of water to ester bonds is considered one of the main reasons for resin degradation within the hybrid layer $[83,84]$. When exposed to oral fluids, the ester bonds within the methacrylate matrix are vulnerable to two forms of hydrolytic attack: (i) chemical hydrolysis catalyzed by acids or bases, and (ii) enzymatic hydrolysis catalyzed by salivary enzymes, particularly esterases. Both require the presence of water in close association with the bond that will be hydrolyzed. Resin degradation is also directly related to water sorption and high water sorption has been reported for hydrophilic resin systems $[70,129]$. These relationships highlight the challenges associated with the development of an adhesive that is resistant to hydrolytic attack, but also miscible with wet demineralized dentin matrices and compatible with our current dental composites.

\section{IV.B. Strategies}

Our strategy for reducing the hydrolytic degradation of methacrylate adhesives while also, promoting bonding to wet dentin has involved a three-pronged scheme. Molecular and mechanical modeling were used in conjunction with synthesis of new methacrylate monomers and multi-scale a/d interfacial characterization. [130,135] Methacrylate side chains have been selectively modified so that they were both water compatible and esterase resistant. [136-140]This was accomplished by using bulky and/ or branched functional groups that were poor esterase substrates but sufficiently hydrophilic to be water compatible. Water-compatible photoinitiators were developed as a means of promoting monomer/polymer conversion and thus, reducing the susceptibility to esterase hydrolysis by reducing the number of unreacted pendant groups [ 11,112,141-143].

Complementary techniques were used to provide in situ detection of the interfacial molecular structure and micro-mechanical features of the a/d interface. The experimental program did not, however, provide complete constitutive behavior. Instead, it provided fragmented information that had to be interpreted and unified.

In general, material constitutive behavior critically depends upon the mechanisms that occur at scales smaller than the material-scale. Thus, our research team developed modeling methodologies to account for these underlying mechanisms. The modeling in conjunction with our multi-scalar structure/ property characterization has allowed us to project the long-term mechanical durability of the novel water-compatible, esterase-resistant adhesives under conditions that simulate function in the mouth $[28,29,49,50,54,68,69,74,76,82,111,131,133-$ 140,143-160] .

In summary, factors that prohibit the formation of an ideal hybrid layer and a durable a/d bond include inadequate monomer/polymer conversion, adhesive phase separation, water sorption and hydrolysis of the adhesive. These factors may be addressed by using an iterative combinatorial optimization (molecular design)/synthesis approach in conjunction with a/d interfacial multi-scale characterization and modeling to design, synthesize and develop water-compatible, esterase-resistant methacrylate-based dentin adhesives $[28,29,49,50,54,55,68,69,74,76,78,82,86$, $96,97,110,112,131,137,138,140,144,145$, 147, 150, 154, 155, 158-169]. Finite element (FE) modeling is used to project the long-term mechanical durability of the new adhesives under conditions that simulate function in the mouth $[149,150]$.

\section{Biofilms, Dental Plaque and S. mutans}

The failure of the $\mathrm{a} / \mathrm{d}$ bond in concert with reports of increased levels of cariogenic bacteria at the perimeter of composite materials points to an interesting interplay between microbiology and adhesive degradation as 
key elements in the premature failure of moderate-tolarge composite restorations. Adhesion of S. mutans to surfaces in the mouth creates an environment that supports the subsequent attachment and growth of other bacterial species, ultimately forming a microecosystem known as a biofilm.

In the oral cavity, microorganisms mainly exist as biofilms on saliva-coated surfaces, e.g. teeth, restorative materials, and so forth. The key interaction in the initiation of biofilm development is the adhesion of primary microorganisms to a surface. The pioneer bacteria then recruit other bacteria by providing a new surface and metabolic products that facilitate the succeeding attachments. Streptococci constitute $>60 \%$ of the bacteria found in the early communities in saliva-coated tooth enamel. [170] The initial colonization involves interaction of bacterial cell surface proteins with saliva components (dental pellicle) adsorbed to the tooth surface. Salivary agglutinin, a $\sim 400 \mathrm{kDa}$ oligomeric complex of the cysteine-rich glycoprotein gp340, is the key component of the saliva that mediates the attachment with the bacterial cell surface proteins. [171] For cariogenic S. mutans, antigen I/II (AgI/II), also known as $\mathrm{SpaP}$ or $\mathrm{P} 1$, is the cell surface protein that interacts with gp340 to attach them to dental pellicle.

[172] After the initial attachment, S. mutans synthesizes glucans (extracellular polysaccharides) from sucrose when it is present, by glucosyltransferases (GTFs). The glucans then interact with glucan-binding proteins (GBPs) and with the glucan-binding domain of GTFs, both of which are present at the surface of $\mathrm{S}$ mutans. The primary aggregation of these bacteria on the tooth surface serves as a platform for the attachment of other bacteria for the accumulation of biofilms, known as dental plaques. Thus, the key step in the accumulation of dental plaque is the initial interaction of bacterial $\mathrm{P} 1$ protein with the salivary agglutinin gp340.

\section{V.A. Salivary Agglutinin GP340}

Investigators have reported a positive correlation of the protein, gp340, with caries experience and saliva adhesion of S. mutans. [173] Specific amino acid sequences involved in P1 interaction with gp340 have been identified, [174] and peptide vaccines based on these sequences have been shown to be effective in preventing S. mutans attachment both in vitro and in clinical trials. [175] We are intrigued by the role of the solid surface in S. mutans attachment, particularly with regard to its influence on the critical protein-protein interactions. These effects are not well understood at the molecular level. While there have been studies documenting surface effects on S. mutans attachment [176-178] most have employed whole-cell assays of attachment. These studies have helped to demonstrate that the surface does, in fact, influence bacterial attachment, but provide little information on the particular chemical interactions involved. Lack of information at the chemical level precludes the rational design of materials that limit bacterial adhesion, since the relevant structureproperty relationships are not known.

Studies by Ligtenberg and others [179] have suggested that the interaction of S. mutans with the surface is influenced by the extent of gp340 binding. It is not known how gp340 interacts with the methacrylate adhesive, but this information is vital for understanding how the biofilm is anchored to the adhesive surface. A common approach used to identify specific regions of a protein involved in interaction with another macromolecule is to cleave the protein into smaller peptide fragments and determine which pieces bind to the partner. The salivary agglutinin gp340 was cleaved in this manner, and the fragment primarily responsible for interaction with $\mathrm{P} 1$ from S. mutans was identified. [174] Once an interacting fragment is identified, higher-resolution analyses can be performed to map the chemical moieties in the peptide that directly participate in binding, e.g. a methyl group from an Ala. Solution nuclear magnetic resonance (NMR) spectroscopy is a suitable tool for assessing such site-specific interactions, even when they are weak $(\mu \mathrm{M}-\mathrm{mM} \mathrm{KD})$ as is often the case with peptides. Several NMR experiments reveal binding sites between peptide fragments and large molecules. The bound conformation of the peptide can be determined and this information used to understand how binding occurs. [180] Cross-validation of the involvement of specific moieties is performed by modifying the peptide slightly by blocking or removing specific interactions.

\section{V.B. Novel interventions}

Adhesion of S. mutans to surfaces in the mouth creates an environment that supports the subsequent attachment and growth of other bacterial species, ultimately forming a micro-ecosystem known as a biofilm. Dental plaque biofilm cannot be eliminated, [181] but the pathogenic impact of the biofilm at the margin of the composite restoration could be reduced by engineering novel dentin adhesives that 
limit gp340/S. mutans attachment and neutralize the micro-environment to prevent damage (by lactic acid) to the adjacent tooth structure. Clearly, any change in the chemical structure will likely alter other mechanical and physicochemical properties. The optimal adhesive will be produced by balancing the desired physical, chemical and mechanical properties with the need for limited gp340/S. mutans attachment and neutralization capabilities. The combinatorial optimization approach allows the relative importance of each property to be varied and predicts novel methacrylate structures for further evaluation [131].

Lactic acid (LA) is the primary compound produced during acidification of the oral cavity by microbes. As such, we have developed an NMRbased assay for detecting the solution $\mathrm{pH}$ and changes in $\mathrm{pH}$ of samples containing lactic acid. Because LA is acidic, the addition of basic monomeric units or hydrated polymers that contain buffering moieties alters the $\mathrm{pH}$ of the sample. The degree of change can be tracked and the buffering capacity quantified using our approach. The NMR chemical shift is extremely sensitive to small changes that most other methods cannot detect, making it an excellent probe for monitoring perturbations to the nucleus of interest. Here, the chemical shift of the carbonyl $13 \mathrm{C}$ in LA has been correlated with $\mathrm{pH}$ and monitored as a function of increasing concentration of monomer (Figure 4).

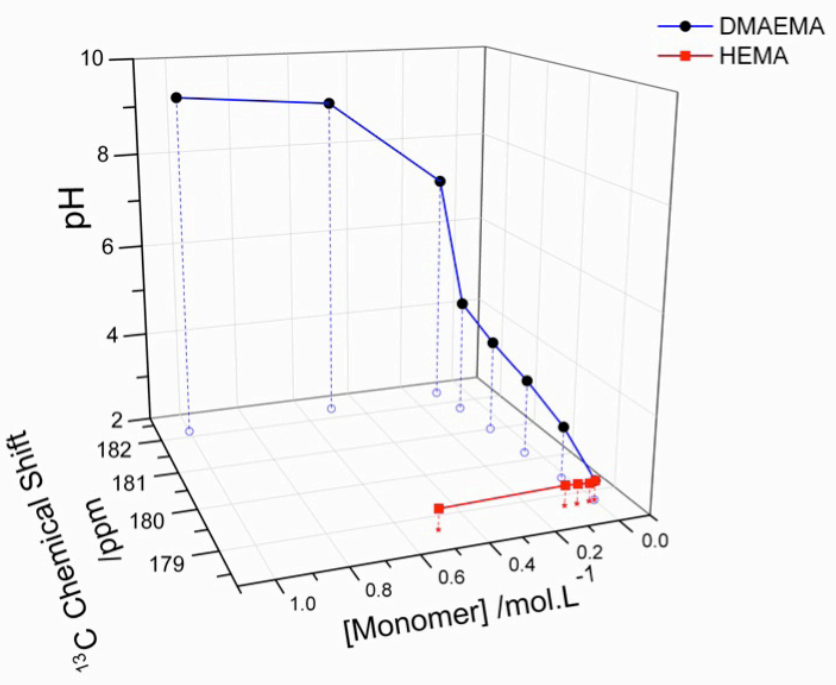

Figure 4 -Three-dimensional plot of $\mathrm{pH}$ vs $13 \mathrm{C}$ NMR chemical shift (ppm) of the carbonyl group $(C=O)$ from lactic acid (LA) in solutions titrated with increasing concentrations of HEMA or DMAEMA monomers. HEMA does not alter the $\mathrm{pH}$ of the $0.1 \mathrm{M}$ LA solution, whereas increasing amounts of DMAEMA demonstrate obvious buffering and neutralization.
As can be seen in this plot, inclusion of HEMA, the monomer currently used in the methacrylate dentin adhesive, even at high concentration in the LA solution, has no impact on the $\mathrm{pH}$ of the solution, and it cannot buffer or neutralize LA. The addition of increasing amounts of 2-dimethyl-aminoethyl methacrylate (DMAEMA), which contains a basic amine, does however, shift the $\mathrm{pH}$ of the acidic LA solution making it more neutral. These data show that neutralization can be achieved by monomers such as DMAEMA and that the buffering capacity can be measured in a simple NMR experiment using LA as a probe [152] .

\section{SummarY}

In summary, the $\mathrm{a} / \mathrm{d}$ bond can be the first defense against substances that may penetrate and ultimately undermine the composite restoration in vivo. In vitro and in vivo studies have suggested that several factors inhibit the formation of a durable $\mathrm{a} / \mathrm{d}$ bond. These factors include: 1) water sorption and hydrolysis of the adhesive resin; 2) inadequate monomer/polymer conversion of the infiltrating adhesive; 3 ) incomplete resin infiltration; 4) incomplete solvent evaporation [ 78,86,182,183]; 5) enzymatic challenges within the cavity preparation $[100]$; 6) surface degradation by biofilms; and 7) substrate characteristics [76,78,161,184-187]. However, as indicated in a recent review of dental composite, the properties of the materials are one part of a complex problem [188]. The success of clinical restorations depends on a variety of factors including proper technique, appropriate materials and proper patient selection [188].

\section{AcKnowledgements}

The authors gratefully acknowledge research support from NIH/NIDCR grants DE014392 (PS), DE022054 (PS, JSL), and K23DE/HD00468 (BSB). We also acknowledge the numerous oral surgeons and their staff who assisted us with these projects. The authors gratefully acknowledge the professors who have inspired us, the students who have worked with us, and the patients who have galvanized our efforts to develop durable materials that will restore form, function and esthetics to tissues damaged as a result of disease, age or trauma. 


\section{Resumo}

Restaurações em resina composta apresentam elevada taxa de falhas, recorrência de cárie e maior necessidade de troca quando comparadas às restaurações em amálgama. A penetração de enzimas bacterianas, fluidos orais e da própria bactéria nas fendas existentes entre o dente e o compósito, enfraquecem a restauração e levam à recorrência de cárie e falhas. A margem gengival das restaurações em resina composta é particularmente vulnerável à cárie e, nesta margem, $\mathrm{o}$ adesivo e o selamento dentinário funcionam como a primeira bareira entre o dente preparado e o ambiente oral. O objetivo deste artigo de revisão é examinar os fatores físico-químicos que afetam a integridade e a durabilidade da interface de adesão adesivo/dentina e explorar como esses fatores agem sinergicamente para minar a restauração de resina composta. A revisão irá examinar as diversas possibilidades para solucionar esses problemas, bem como explorar como alterações na química dos materiais poderiam solucionar o impacto negativo do estresse físico-químico na interface adesiva com a dentina.

\section{Palavras-chave}

Revisão de literatura; adesão; interface dentina/restauração; integridade; durabilidade.

\section{REferences}

1. Beazoglou T, Eklund S, Heffley D, Meiers J, Brown LJ, Bailit H. Economic impact of regulating the use of amalgam restorations. Public Health Reports 2007;122(5):657-63.

2. Murray PE, Windsor LJ, Smyth TW, Hafez AA, Cox CF. Analysis of pulpal reactions to restorative procedures, materials, pulp capping, and future therapies. Crit Rev Oral Biol Med 2002;13(6):509-20.

3. Palmer C. Good progress reported in mercury treaty talks. ADA News 2011;42(21):1-2.

4. Simecek JW, Diefenderfer KE, Cohen ME. An evaluation of replacement rates for posterior resin-based composite and amalgam restorations in US Navy and Marine Corps recruits. Journal of the American Dental Association 2009;140(2):200-9.

5. Bernardo M, Luis H, Martin MD, Leroux BG, Rue T, Leitao J, DeRouen TA. Survival and reasons for failure of amalgam versus composite posterior restorations placed in a randomized clinical trial. Journal of the American Dental Association 2007;138(6):775-83.

6. DeRouen TA, Martin MD, Leroux BG, Townes BD, Woods JS, Leitao J, Castro-Caldas A, Luis H, Bernardo M, Rosenbaum $\mathrm{G}$ and others. Neurobehavioral effects of dental amalgam in children: a randomized clinical trial. Jama 2006;295(15):1784-92.

7. Levin L, Coval M, Geiger SB. Cross-sectional radiographic survey of amalgam and resin-based composite posterior restorations. Quintessence International 2007;38(6):511-14.

8. Mjor IA, Dahl JE, Moorhead JE. Age of restorations at replacement in permanent teeth in general dental practice. Acta Odontologica Scandinavica 2000;58(3):97-101.

9. Opdam NJM, Bronkhorst EM, Loomans BAC, Huysmans M. 12-year Survival of Composite vs. Amalgam Restorations. Journal of Dental Research 2010;89(10):1063-67.

10. Soncini JA, Maserejian NN, Trachtenberg F, Tavares M, Hayes C. The longevity of amalgam versus compomer/ composite restorations in posterior primary and permanent teeth: findings From the New England Children's Amalgam Trial. J Am Dent Assoc 2007;138(6):763-72.

11. DeRouen TA, Martin MD, Leroux BG, Townes BD, Woods JS, Leitao J, Castro-Caldes A, Luis H, Bernardo M,
Rosenbaum G and others. Neurobehavioral effects of dental amalgam in children: a randomized clinical trial. JAMA 2006;295:1784-92.

12. Van Nieuwenhuysen JP, D'Hoore W, Carvalho J, Qvist V. Long-term evaluation of extensive restorations in permanent teeth. J Dent 2003;31(6):395-405.

13. Hunter AR, Treasue ET, Hunter AJ. Increases in Cavity Volume Associated with the Removal of Class 2 Amalgam and Composite Restorations. Operative Dentistry 1995:2-6.

14. Tobi H, Kreulen CM, Vondeling H, van Amerongen WE. Cost-effectiveness of Composite Resins and Amalgam in the Replacement of Amalgam Class II Restorations. Community Dent Oral Epidemiol. 1999;27:137-43.

15. Collins CJ, Bryant RW, Hodge KL. A clinical evaluation of posterior composite resin restorations: 8-year findings. J Dent 1998;26(4):311-7.

16. Mair LH. Ten-year Clinical Assessment of Three Posterior Resin Composites and Two Amalgams. Quintessence Int 1998;29:483-90.

17. Mjor IA, Dahl JE, Moorhead JE. Placement and replacement of restorations in primary teeth. Acta Odontol Scand 2002;60(1):25-8.

18. Nordbo H, Leirskar J, von der Fehr FR. Saucer-shaped Cavity Preparations for Posterior Approximal Resin Composite Restorations: Observations up to 10 Years. Quintessence Int. 1998;29:5-11.

19. Owens BM, Johnson WW. Effect of insertion technique and adhesive system on microleakage of Class $\mathrm{V}$ resin composite restorations. J Adhes Dent 2005 7:303-8.

20. Van Meerbeek B, Van Landuyt K, De Munck J, Hashimoto M, Peumans M, Lambrechts P, Yoshida Y, Inoue S, Suzuki K. Technique-sensitivity of contemporary adhesives. Dent Mater J 2005;24(1):1-13.

21. Anusavice KJ. Management of dental caries as a chronic infectious disease. J Dent Educ 1998;62:791-802.

22. Dunne SM, Gainsford ID, Wilson NHF. Current materials and techniques for direct restorations in posterior teeth. Part 1: silver amalgam. International Dental Journal 1997;47:12336.

23. Hansel C, Leyhausen G, Mai UE, Geurtsen W. Effects of various resin composite (co)monomers and extracts on two caries-associated micro-organisms in vitro. J Dent Res 1998;77:60-7. 
24. Santerre JP, Shajii L, Leung BW. Relation of dental composite formulations to their degradation and the release of hydrolyzed polymeric-resin-derived products. Crit Rev Oral Biol Med 2001;12:136-51.

25. Svanberg M, Mjor IA, Orstavik D. Mutans Streptococci in Plaque from Margins of Amalgam Composite, and Glass-ionomer Restorations. Journal of Dental Research 1990;69(3):861-4.

26. Hashimoto M, Ohno H, Kaga M, Endo K, Sano H, Oguchi $\mathrm{H}$. Resin-tooth adhesive interfaces after long-term function. Am J Dent 2001;14(4):211-5.

27. Meiers JC, Kresin J. Cavity disinfectants and dentin bonding. Oper Dent 1996;21:153-9.

28. Spencer P, Wang Y, Bohaty B. Interfacial chemistry of moisture-aged class II composite restorations. J Biomed Mater Res B Appl Biomater 2006;77(2):234-40.

29. Wang Y, Spencer P. Interfacial chemistry of class II composite restoration: structure analysis. J Biomed Mater Res A 2005;75(3):580-7.

30. Gallo LM, Nickel JC, Iwasaki LR, Palla S. Stress-field Translation in the Healthy Human Temporomandibular Joint. J Dent Res 2000;79(10):1740-6.

31. Andersson-Wenckert IE, van Dijken JW, Kieri C. Durability of extensive Class II open-sandwich restorations with a resin-modified glass ionomer cement after 6 years. Am J Dent 2004 17:43-50.

32. Brannstrom M. Communication between the oral cavity and the dental pulp associated with restorative treatment. Oper Dent 1984 9(57-68).

33. Breschi L, Mazzoni A, Ruggeri A, Cadenaro M, DiLenarda R, DeStefano Dorigo E. Dental adhesion review: Aging and stability of the bonded interface. Dent Mater (in press) 2007.

34. Roulet JF. Benefits and Disadvantages of Tooth-coloured Alternatives to Amalgam. J. Dent 1997;25:459-73.

35. Van Dijken JW. Direct resin composite inlays/onlays: an 11 year follow-up. J. Dent 2000;28:299-306.

36. Kleverlaan CJ, Feilzer AJ. Polymerization shrinkage and contraction stress of dental resin composites. Dent Mater 2005 21:1150-7.

37. Bouillaguet S, Ciucchi B, Jacoby T, Wataha JC, Pashley D. Bonding characteristics to dentin walls of class II cavities, in vitro. Dental Materials 2001 17:316-21.

38. Purk JH, Dusevich V, Glaros AG, Spencer P, Eick JD. In vivo versus in vitro microtensile bond strength of axial versus gingival cavity preparation walls in Class II resin-based composite restorations. JADA 2004;135:185-93.

39. Garberoglio $P$. The ratio of the densities of dentinal tubules on the cervical and axial wall in cavities. Quintessence Int 1994;25:49-52.

40. Yoshiyama M, Carvalho R, Sano H, Horner J, Brewer PD, Pashley DH. Interfacial Morphology and Strength of Bonds Made to Superficial Versus Deep Dentin. American Journal of Dentistry 1995;8:297-302.

41. Pashley DH. Clinical correlations of dentin structure and function. J Prosthet Dent 1991 66:777-81.

42. Eick JD, Cobb CM, Chappell RP, Spencer P, Robinson SJ. The dentinal surface: Its influence on dentinal adhesion. Part III. Quintessence Int 1993;24:571-582.

43. Gwinnett AJ, Tay FR, Pang KM, Wei SHY. Quantitative Contribution of the Collagen Network in Dentin Hybridization. American Journal of Dentistry 1996;9:140-4.

44. Hashimoto $\mathrm{M}$, Ohno H, Sano H, Kaga M, Oguchi H. In vitro degradation of resin-dentin bonds analyzed by microtensile bond test, scanning and transmission electron microscopy. Biomaterials 2003;24(21):3795-803.

45. Perdigao J, Swift EJ, Denehy GE, Wefel JS, Donly KJ. In vitro bond strengths and SEM evaluation of dentin bonding systems to different dentin substrates. J. Dent. Res. 1994; 73:44-55.

46. Tam LE, Pilliar RM. Fracture Surface Characterization of Dentin-bonded Interfacial Fracture Toughness Specimens. Journal of Dental Research 1994;73(3):607-19.

47. Erickson RL. Surface Interactions of Dentin Adhesive Materials. Operative Dentistry, Supplement 5 1992:81-94.

48. Hashimoto M, Ohno H, Endo K, Kaga M, Sano H, Oguchi $\mathrm{H}$. The effect of hybrid layer thickness on bond strength: demineralized dentin zone of the hybrid layer. Dent Mat 2000;16:406-11.

49. Spencer P, Swafford JR. Unprotected protein at the dentinadhesive interface. Quintessence Int 1999;30(7):501-7.

50. Wang Y, Spencer P. Hybridization efficiency of the adhesive dentin interface with wet bonding. J. Dent. Res. 2003;82:1415.

51. Nakabayashi N, Kojima K, Masuhara E. The promotion of adhesion by the infiltration of monomers into tooth substrates. J. Biomed. Mater. Res. 1982;16:265-73.

52. Nakabayashi N, Pashley DH. Hybridization of Dental Hard Tissues. Tokyo: Quintessence Publishing Co, Ltd; 1998.

53. Eick JD, Gwinnet AJ, Pashley DH, Robinson SJ. Current concepts on adhesion to dentin. Critical Reviews in Oral Biology \& Medicine 1997;8:306-35.

54. Wang Y, Spencer P. Quantifying Adhesive Penetration in Adhesive/Dentin Interface Using Confocal Raman Microspectroscopy. J. Biomed. Mater. Res. 2002;59:46-55.

55. Wang Y, Spencer P. Overestimating hybrid layer quality in polished adhesive/dentin interfaces. J Biomed Mater Res 2004;68A:735-46.

56. Marshall J, G.W.Dentin: Microstructure and Characterization. Quint. Int 1993;24:606-17.

57. Pashley DH, Ciucchi B, Sano H, Horner JA. Permeability of Dentin to Adhesive Agents. Quintessence International 1993;24:618-31.

58. Gwinnett AJ. Quantitative Contribution of Resin Infiltration/ Hybridization to Dentin Bonding. Am. J. Dent. 1993;6:7-9.

59. Inokoshi S, Nakaoki Y, Shono T, Pereira PNR, Yamada T, Tagami J. Collagen layer collapse and inhibited resin penetration by dentin etching. J. Dent. Res. 1996;75:389, abstract \#2976.

60. Wieliczka DM, Kruger MB, Spencer P. Raman Imaging of Dental Adhesive Diffusion. Applied Spectroscopy 1997;51:1593-6.

61. Gwinnett AJ. Chemically Conditioned Dentin: a Comparison of Conventional and Environmental Scanning Electron Microscopy Findings. Dental Materials 1994;10:150-5.

62. Gwinnett AJ. Dentin bond strength after air drying and rewetting. Am. J. Dent. 1994;7:144-8.

63. Gwinnett AJ. Altered tissue contribution to interfacial bond strength with acid conditioned dentin. Am. J. Dent. 1994;7:243-6.

64. Kanca J. Improved bond strength through acid etching of dentin and bonding to wet dentin surfaces. J. Am Dent Assoc 1992; 123:235-43.

65. Kinney J, H., Balooch M, Marshall SJ, Marshall GW. Atomic force microscope study of dimensional changes in dentine during drying. Arch. Oral Biol. 1993;38:1003-7.

66. Nakabayashi N, Watanabe A, Arao T. A tensile test to 
facilitate identification of defects in resin-bonded dentin specimens. J. Dent 1998;26:379-85.

67. Pashley EL, Zhang Y, Lockwood PE, Rueggeberg FA, Pashley DH. Effects of HEMA on water evaporation from water-HEMA mixtures. Dent Mater 1998;14(1):6-10.

68. Spencer P, Wang Y. Adhesive phase separation at the dentin interface under wet bonding conditions. J Biomed Mater Res 2002;62(3):447-56

69. Spencer P, Wang Y, Walker MP, Wieliczka DM, Swafford JR. Interfacial chemistry of the dentin/adhesive bond. J Dent Res 2000;79(7):1458-63.

70. Ito S, Hashimoto M, Wadgaonkar B, Svizero N, Carvalho RM, Yiu C, Rueggeberg FA, Foulger S, Saito T, Nishitani $\mathrm{Y}$ and others. Effects of resin hydrophilicity on water sorption and changes in modulus of elasticity. Biomaterials 2005;26(33):6449-59.

71. Marshall GW, Marshall SJ, Kinney JH, Balooch M. The dentin substrate:structure and properties related to bonding. J Dent 1997;25:441-58.

72. Pereira PNR, Okuda M, Sano H, Yoshikawa T, Burrow MF, Tagami J. Effect of Intrinsic Wetness and Regional Difference on Dentin Bond Strength. Dental Materials 1999;15:46-53.

73. Roulet JF, Degrange M, editors. Adhesion: The Silent Revolution in Dentistry. First ed: Quintessence Publishing Co., Inc.; 1999. p263 p.

74. Wang Y, Spencer P, Hager C, Bohaty B. Comparison of interfacial characteristics of adhesive bonding to superficial versus deep dentin using SEM and staining techniques. J. Dent 2006;34:26-34.

75. Pashley DH. Dentin: A dynamic substrate in dentistry. Scanning Microscopy 1989;3:161-76.

76. Spencer P, Wang Y, Katz JL, Misra A. Physicochemical interactions at the dentin/adhesive interface using FTIR chemical imaging. J Biomed Opt 2005;10(3):031104.

77. Wang Y, Spencer P. Continuing etching of an all-in-one adhesive in wet dentin tubules. J. Dent. Res. 2005;84:350-4.

78. Wang Y, Spencer P, Yao X, Brenda B. Effect of solvent content on resin hybridization in wet dentin bonding. J Biomed Mater Res A 2007;82(4):975-83.

79. Tay FR, Gwinnett AJ, Pang KM, Wei SHY. An optical, micromorphological study of surface moisture in the total etched resin-dentin interface. Am. J. Dent. 1996;9:43-8.

80. Tay FR, Gwinnett AJ, Wei SHY. The Overwet Phenomenon: A Transmission Electron Microscopic Study of Surface Moisture in the Acid-Conditioned, Resin-Dentin Interface. Am. J. Dent. 1996;9:161-6.

81. Tay FR, Gwinnett AJ, Wei SHY. Micromophological sepctrum from overdrying to overwetting acid-conditioned dentin in water-free, acetone-based, single-bottle primer/ adhesives. Dent Mater 1996;12:236-44.

82. Wang $Y$, Spencer $\mathrm{P}$, Yao X. Micro-Raman Imaging Analysis of Monomer/Mineral Distribution in Intertubular Region of Adhesive/Dentin Interfaces. J Biomed Optics 2006;11:024005-1 to 024005-7.

83. Tay FR, Pashley DH. Water treeing--a potential mechanism for degradation of dentin adhesives. Am J Dent 2003;16(1):612.

84. Tay FR, Pashley DH. Have dentin adhesives become too hydrophilic? J Can Dent Assoc 2003;69(11):726-31.

85. Nishitani Y, Yoshiyama M, Donnelly AM, Agee KA, Sword J, Tay FR, Pashley DH. Effects of resin hydrophilicity on dentin bond strength. J Dent Res 2006;85(11):1016-21.

86. Ye Q, Spencer P, Wang Y, Misra A. Relationship of solvent to the photopolymerization process, properties, and structure in model dentin adhesives. J Biomed Mater Res A 2007;80(2):342-50.

87. Hebling J, Pashley DH, Tjaderhane L, Tay FR. Chlorhexidine Arrests Subclinical Degradation of Dentin Hydbrid Layers in vivo. J Dent Res 2005;84(8):741-6.

88. Frankenberger R, Pashley DH, Reich SM, Lohbauer U, Petschelt A, Tay FR. Characterisation of resin-dentine interfaces by compressive cyclic loading. Biomaterials 2005;26(14):2043-52.

89. Okuda M, Pereira PN, Nakajima M, Tagami J, Pashley DH. Long-term durability of resin dentin interface: nanoleakage vs. microtensile bond strength. Oper Dent 2002 27:289-96.

90. Yiu CK, King NM, Pashley DH, Suh BI, Carvalho RM, Carrilho MR, Tay FR. Effect of resin hydrophilicity and water storage on resin strength. Biomaterials 2004;25(26):578996.

91. Peumans M, Kanumilli P, De Munck J, Van Landuyt K, Lambrechts P, Van Meerbeek B. Clinical effectiveness of contemporary adhesives: a systematic review of current clinical trials. Dent Mater 2005;21(9):864-81.

92. Donmez N, Belli S, Pashley DH, Tay FR. Ultrastructural correlates of in vivo/in vitro bond degradation in self-etch adhesives. Journal of Dental Research 2005;84(4):355-9.

93. Burrow MF, Satoh M, Tagami J. Dentin durability after three years using a dentin bonding agent with and without priming. Dent Mater 1996;12:302-7.

94. Hashimoto M, Ohno H, Kaga M, Sano H, Endo K, Oguchi $\mathrm{H}$. The extent to which resin can infiltrate dentin by acetonebased adhesives. J. Dent. Res. 2002;81(1):74-8.

95. Sano H, Yoshikawa T, Pereira PNR, Kanemura N, Morigami M, Tagami J, Pashley DH. Long-term Durability of Dentin Bonds Made with a Self-etching Primer, in vivo. J Dent Res 1999;78(4):906-11.

96. Wang Y, Spencer P. Exploring the nature of acid-resistant hybrid layer with wet bonding. Oper Dent 2004;29:650-655.

97. Wang Y, Spencer P. Physicochemical Interactions at the Interfaces Between Self-Etch Adhesive Systems and Dentin. J. Dent 2004;32:567-79.

98. Spencer P, Ye Q, Park J, Topp EM, Misra A, Marangos O, Wang Y, Bohaty BS, Singh V, Sene F and others. Adhesive/ Dentin interface: the weak link in the composite restoration. Ann Biomed Eng 2010;38(6):1989-2003.

99. Hashimoto M. A review--micromorphological evidence of degradation in resin-dentin bonds and potential preventional solutions. J Biomed Mater Res B Appl Biomater 2010;92(1):268-80.

100. Pashley DH, Tay FR, Yiu C, Hashimoto M, Breschi L, Carvalho RM, Ito S. Collagen Degradation by Host-derived Enzymes during Aging. J Dent Res 2004;83(3):216-21.

101. Sano H. Microtensile testing, nanoleakage, and biodegradation of resin-dentin bonds. J Dent Res 2006 85:11-4.

102. Mazzoni A, Pashley DH, Nishitani Y, Breschi L, Tjaderhane L, Toledano M. Reactivation of quenched endogenous proteolytic activities in phosphoric acid-etched dentine by etch-and-rinse adhesives. Biomaterials 2006; In Press.

103. Tay FR, Pashley DH, Loushine RJ, Weller RN, Monticelli F, Osorio R. Self-etching adhesives increase collagenolytic activity in radicular dentin. Journal of Endodontics 2006;32(9):862-8.

104. Gu LS, Kim J, Kim YK, Liu Y, Dickens SH, Pashley DH, Ling JQ, Tay FR. A chemical phosphorylation-inspired 
design for Type I collagen biomimetic remineralization. Dent Mater 2010;26(11):1077-89.

105. Brackett MG, Li N, Brackett WW, Sword RJ, Qi YP, Niu LN, Pucci CR, Dib A, Pashley DH, Tay FR. The critical barrier to progress in dentine bonding with the etch-and-rinse technique. J Dent 2011;39(3):238-48.

106. Sadek FT, Braga RR, Muench A, Liu Y, Pashley DH, Tay FR. Ethanol wet-bonding challenges current anti-degradation strategy. J Dent Res 2010;89(12):1499-504.

107. Tezvergil-Mutluay A, Agee KA, Uchiyama T, Imazato S, Mutluay MM, Cadenaro M, Breschi L, Nishitani Y, Tay FR, Pashley DH. The inhibitory effects of quaternary ammonium methacrylates on soluble and matrix-bound MMPs. J Dent Res 2011;90(4):535-40.

108. Coutinho E, Cardoso MV, Fernandes CP, Neves AA, Gouvea CV, Van Landuyt KL, De Munck J, Van Meerbeek B. Nanoleakage distribution at adhesive-dentin interfaces in 3D. J Dent Res 2011;90(8):1019-25.

109. Kermanshahi S, Santerre JP, Cvitkovitch DG, Finer Y. Biodegradation of resin-dentin interfaces increases bacterial microleakage. J Dent Res 2010;89(9):996-1001.

110. Wang Y, Spencer P, Yao X, Ye Q. Effect of coinitiator and water on the photoreactivity and photopolymerization of HEMA/camphoquinone-based reactant mixtures. J Biomed Mater Res A 2006;78(4):721-8.

111. Ye Q, Park J, Pamatmat F, Misra A, Laurence JS, Parthasarathy R, Marangos O, Spencer P. Quantitative Analysis of Aqueous Phase Composition of Model Dentin Adhesives Experiencing Phase Separation. J Biomed Mater Res B Appl Biomater 2012; accepted.

112. Ye Q, Park J, Topp E, Spencer P. Effect of photoinitiators on the in vitro performance of a dentin adhesive exposed to simulated oral environment. Dent Mater 2009;25(4):452-8.

113. Tay FR, Hashimoto M, Pashley DH, Peters MC, Lai SC, Yiu CK, Cheong C. Aging affects two modes of nanoleakage expression in bonded dentin. J Dent Res 2003 82:537-41.

114. De Munck J, Van Landuyt K, Peumans M, Poitevin A, Lambrechts P, Braem M, Van Meerbeek B. A Critical Review of the Durability of Adhesion to Tooth Tissue: Methods and Results. J Dent Res 2005;84(2):118-32.

115. Pashley DH, Tay FR, Hashimoto M, Breschi L, Carvalho RM, Ito S. Degradation of dentin collagen by host-derived enzymes during aging. J Dent Res 2004;83:216-21.

116. Yoshida E, Uno S, Nodasaka Y, Kaga M, Hirano S. Relationship between water status in dentin and interfacial morphology in all-in-one adhesives. Dent Mater 2007;23(5):556-60.

117. Humphrey SP, Williamson RT. A review of saliva: normal composition, flow, and function. Journal of Prosthetic Dentistry 2001;85:162-9.

118. Labow RS, Duguay DG, Santerre JP. The enzymatic hydrolysis of a synthetic biomembrane: a new substrate for cholesterol and carboxyl esterases. J Biomater Sci Polym Ed 1994;6:169-79.

119. Lee YK, Powers JM. Influence of salivary organic substances on the discoloration of esthetic dental materials-a review. Journal of Biomedical Materials Research 2006;76:397-402.

120. Levine MJ. Salivary macromolecules. A structure/function synopsis. Annals of the New York Academy of Sciences 1993;694:11-6.

121. Wadgaonkar B, Ito S, Svizero N, Elrod D, Foulger S, Rodgers R, Oshida Y, Kirkland K, Sword J, Rueggeberg F and others. Evaluation of the effect of water-uptake on the impedance of dental resins. Biomaterials 2006;27:3287-94.

122. Finer Y, Jaffer F, Santerre JP. Mutual influence of cholesterol esterase and pseudocholinesterase on the biodegradation of dental composites. Biomaterials 2004 25:1787-93.

123. Finer Y, Santerre JP. The influence of resin chemistry on a dental composite's biodegradation. Journal of Biomedical Materials Research 2004;69A:233-46.

124. Finer Y, Santerre JP. Salivary esterase activity and its association with the biodegradation of dental composites. Journal of Dental Research 2004;83:22-6.

125. Munksgaard EC, Freund M. Enzymatic hydrolysis of (di) methacrylates and their polymers. Scandinavian Journal of Dental Research 1990;98:261-7.

126. Yourtee DM, Smith RE, Russo KA, Burmaster S, Cannon JM, Eick JD, Kostoryz EL. The stability of methacrylate biomaterials when enzyme challenged: Kinetic and systematic evaluations. Journal of Biomedical Materials Research 2001;57(4):523-31.

127. Hagio M, Kawaguchi M, Motokawa W, Mizayaki K. Degradation of Methacrylate Monomers in Human Saliva. Dental Materials Journal 2006;25(2):241-6.

128. Jaffer F, Finer Y, Santerre JP. Interactions between resin monomers and commercial composite resins with human saliva derived esterases. Biomaterials 2002 23:1707-19.

129. Malacarne J, Carvalho RM, de Goes MF, Svizero N, Pashley DH, Tay FR, Yiu CK, Carrilho MR. Water sorption/solubility of dental adhesive resins. Dent Mater 2006;22(10):973-80.

130. Eslick J, Shulda SM, Spencer P, Camarda KV. Optimizationbased Approaches to Computational Molecular Design. In: Adjiman C, Galindo A, editors. Process Systems Engineering: Vol. 6 Molecular Systems Engineering. Weinheim, Germany: Wiley-VHC; 2010.

131. Eslick J, Ye Q, Park J, Topp EM, Spencer P, Camarda KV. A computational molecular design framework for crosslinked polymer networks. Computers and Chemical Engineering 2009;33:954-63.

132. Marangos O, Misra A, Spencer P; Portable sampleholder tracking system for homotopic cross-instrument measurements in microscopy/spectroscopy spectroscopy, United States Provisional Patent Application, ID 09KU081M, filed on June 23, 2009. 2009.

133. Marangos O, Misra A, Spencer P, Katz JL. Scanning acoustic microscopy investigation of frequency-dependent reflectance of acid- etched human dentin using homotopic measurements. IEEE Trans Ultrason Ferroelectr Freq Control 2011;58(3):585-95.

134. Singh V, Misra A, Marangos O, Park J, Ye Q, Kieweg SL, Spencer P. Viscoelastic and fatigue properties of model methacrylate-based dentin adhesives. J Biomed Mater Res B Appl Biomater 2010;95(2):283-90.

135. Singh V, Misra A, Marangos O, Park J, Ye Q, Kieweg SL, Spencer P. Fatigue life prediction of dentin-adhesive interface using micromechanical stress analysis. Dent Mater 2011;27(9):e187-95.

136. Park J, Ye Q, Singh V, Kieweg SL, Misra A, Spencer P. Synthesis and evaluation of novel dental monomer with branched aromatic carboxylic acid group. Journal of Biomedical Materials Research Part B-Applied Biomaterials 2012;100B(2):569-76.

137. Park JG, Ye Q, Topp EM, Kostoryz EL, Wang Y, Kieweg SL, Spencer P. Preparation and properties of novel dentin adhesives with esterase resistance. Journal of Applied Polymer Science 2008;107(6):3588-97. 
138. Park JG, Ye Q, Topp EM, Lee CH, Kostoryz EL, Misra A, Spencer P. Dynamic mechanical analysis and esterase degradation of dentin adhesives containing a branched methacrylate. J Biomed Mater Res B Appl Biomater 2009;91(1):61-70.

139. Park JG, Ye Q, Topp EM, Misra A, Spencer P. Water sorption and dynamic mechanical properties of dentin adhesives with a urethane-based multifunctional methacrylate monomer. Dent Mater 2009;25(12):1569-75.

140. Park JG, Ye Q, Topp EM, Spencer P. Enzyme-catalyzed hydrolysis of dentin adhesives containing a new urethanebased trimethacrylate monomer. J Biomed Mater Res B Appl Biomater 2009;91(2):562-71.

141. Guo X, Peng Z, Spencer P, Wang Y. Effect of initiator on photopolymerization of acidic, aqueous dental model adhesives. J Biomed Mater Res A 2009;90(4):1120-7.

142. Guo X, Wang Y, Spencer P, Ye Q, Yao X. Effects of water content and initiator composition on photopolymerization of a model BisGMA/HEMA resin. Dent Mater 2008;24(6):82431.

143. Park J, Ye Q, Topp EM, Misra A, Kieweg SL, Spencer P. Effect of photoinitiator system and water content on dynamic mechanical properties of a light-cured bisGMA/HEMA dental resin. J Biomed Mater Res A 2010;93(4):1245-51.

144. Guo X, Spencer P, Wang Y, Ye Q, Yao X, Williams K. Effects of a solubility enhancer on penetration of hydrophobic component in model adhesives into wet demineralized dentin. Dent Mater 2007;23(12):1473-81.

145. Katz JL, Bumrerraj S, Dreyfuss J, Wang Y, Spencer P. Micromechanics of the Dentin/Adhesive Interface. J. Biomed. Mater. Res. (Appl Biomater) 2001;58:366-71.

146. Katz JL, Kinney JH, Spencer P, Wang Y, Fricke B, Walker MP, Friis EA. Elastic Anisotropy of Bone and Dentitional Tissues. . J Mater Sci, Materials in Medicine 2005;16:803-6.

147. Katz JL, Spencer P, Nomura T, Wagh A, Wang Y. Micromechanical Properties of Demineralized Dentin Collagen With and Without Adhesive Infiltration. J. Biomed. Mater. Res. 2003;66A:120-8.

148. Marangos O, Misra A, Spencer P, Bohaty B, Katz JL. Physico-mechanical properties determination using microscale homotopic measurements: application to sound and caries-affected primary tooth dentin. Acta Biomater 2009;5(4):1338-48.

149. Misra A, Spencer P, Marangos O, Wang Y, Katz JL. Micromechanical analysis of dentin/adhesive interface using finite element method. J. Biomed. Mater. Res. 2004;70B:5665.

150. Misra A, Spencer P, Marangos O, Wang Y, Katz JL. Parametric study of the Effect of Phase Anisotropy on the Micromechanical Behavior of Dentin/Adhesive Interfaces. . J R Soc Interface 2005;2:145-57.

151. Park J, Eslick J, Ye Q, Misra A, Spencer P. The influence of chemical structure on the properties in methacrylate-based dentin adhesives. Dent Mater 2011;27:1086-93.

152. Park J, Ye Q, Spencer P, Laurence JS. Determination of neutralization capacity and stability of a basic methacrylate monomer using NMR. Int J Polym Mater 2012;61:144-53.

153. Parthasarathy R, Thiagarajan G, Yao X, Wang YP, Spencer P, Wang Y. Application of multivariate spectral analyses in micro-Raman imaging to unveil structural/chemical features of the adhesive/dentin interface. J Biomed Opt 2008;13(1):014020.

154. Spencer P, Wang Y, Katz JL. Identification of collagen encapsulation at the dentin/adhesive interface. J. Adhesive Dent. 2004;6:91-95.

155. Spencer P, Wang Y, Walker MP, Swafford JR. Molecular Structure of Acid-Etched Dentin Smear Layers-In Situ Study. J. Dent. Res. 2001;80:1802-7.

156. Wang Y, Spencer P, Walker MP. Chemical profile of adhesive/caries-affected dentin interfaces using Raman microspectroscopy. J Biomed Mater Res A 2007;81(2):27986.

157. Ye Q, Park J, Laurence JS, Parthasarathy R, Misra A, Spencer P. Ternary Phase Diagram of Model Dentin Adhesive Exposed to Over-wet Environments. J Dent Res 2011;90(12):1434-8.

158. Ye Q, Park JG, Topp E, Wang Y, Misra A, Spencer P. In vitro performance of nano-heterogeneous dentin adhesive. J Dent Res 2008;87(9):829-33.

159. Ye Q, Spencer P, Wang Y. Nanoscale Patterning in Crosslinked Methacrylate Copolymer Networks: An Atomic Force Microscopy Study. J Appl Polym Sci Symp 2007;106(6):3843-51.

160. Ye Q, Wang Y, Spencer P. Nanophase separation of polymers exposed to simulated bonding conditions. J Biomed Mater Res B Appl Biomater 2009;88(2):339-48.

161. Haj-Ali R, Walker MP, Williams K, Wang Y, Spencer P. Histomorphologic Characterization of Non-carious and Caries-Affected Dentin/ Adhesive Interfaces. J Prosthodontics 2006;15:82-88.

162. Katz JL, Misra A, Spencer P, Wang Y, Bumrerraj S, Nomura T, Eppell SJ, Tabib-Azar M. Multiscale mechanics of hierarchical structure/property relationships in calcified tissues and tissue/material interfaces. Materials Science \& Engineering C-Biomimetic and Supramolecular Systems 2007;27(3):450-68.

163. Katz JL, Wang Y, Bumrerraj S, Nomura T, Misra A, Eppell SJ, Tabib-Azar M, Spencer P. Functional Imaging of the Hierarchical Structure/Property Relationships in Bone, Dentin and the Dentin/Adhesive Interface. In: Nalwa HS, editor. Handbook of Nanostructured Biomaterials and Their Applications,. Stevenson Ranch, CA: American Scientific Publishers; 2005.

164. Kostoryz EL, Dharmala K, Ye Q, Wang Y, Huber J, Park JG, Snider G, Katz JL, Spencer P. Enzymatic biodegradation of HEMA/bisGMA adhesives formulated with different water content. J Biomed Mater Res B Appl Biomater 2009;88(2):394-401.

165. Park J, Spencer P, Topp L, Ye Q; Novel Monomer for Dental Adhesive, United States Patent, PROVISIONAL PATENT APPLICATION, Serial No.61/041/401. 2008.

166. Thiagarajan G, Deshmukh K, Wang Y, Misra A, Katz JL, Spencer P. Nano finite element modeling of the mechanical behavior of biocomposites using multi-scale (virtual internal bond) material models. J Biomed Mater Res A 2007;83(2):332-44.

167. Wang Y, Spencer P. Analysis of acid-treated dentin smear debris and smear layers using confocal Raman microspectroscopy. J. Biomed. Mater. Res. 2002;60:300-8.

168. Wang Y, Spencer P. Effect of acid etching time and techniques on interfacial characteristics of the adhesive-dentin bond using differential staining. Eur J Oral Sci 2004;112:293-299.

169. Wang Y, Spencer P. Evaluation of the Interface between OneBottle Adhesive Systems and Dentin by Goldner's Trichrome Stain. Am. J. Dent. 2005;18:66-72.

170. Nyvad B, Kilian M. Microbiology of the early colonization 
of human enamel and root surfaces in vivo. Scand J Dent Res 1987;95(5):369-80.

171. Loimaranta V, Jakubovics NS, Hytonen J, Finne J, Jenkinson HF, Stromberg N. Fluid- or surface-phase human salivary scavenger protein gp340 exposes different bacterial recognition properties. Infect Immun 2005;73(4):2245-52.

172. Jenkinson HF, Demuth DR. Structure, function and immunogenicity of streptococcal antigen I/II polypeptides. Mol Microbiol 1997;23(2):183-90.

173. Jonasson A, Eriksson C, Jenkinson HF, Kallestal C, Johansson I, Stromberg N. Innate immunity glycoprotein gp340 variants may modulate human susceptibility to dental caries. BMC Infect Dis 2007;7:57.

174. Bikker FJ, Ligtenberg AJ, Nazmi K, Veerman EC, van't Hof W, Bolscher JG, Poustka A, Nieuw Amerongen AV, Mollenhauer J. Identification of the bacteria-binding peptide domain on salivary agglutinin (gp-340/DMBT1), a member of the scavenger receptor cysteine-rich superfamily. J Biol Chem 2002;277(35):32109-15.

175. Younson J, Kelly C. The rational design of an anti-caries peptide against Streptococcus mutans. Molecular Diversity 2004;8:121-26.

176. Buergers R, Schneider-Brachert W, Hahnel S, Rosentritt M. Streptococcal adhesion to novel low-shrink silorane-based restorative Dental Materials 2009;25(2):269-75.

177. Edgerton M, Lo SE, Scannapieco FA. Experimental salivary pellicles formed on titanium surfaces mediate adhesion of streptococci. Int J Oral Maxillofac Implants 1996;11(4):443-9.

178. Pereira-Cenci T, Cenci MS, Fedorowicz Z, Marchesan MA. Antibacterial agents in composite restorations for the prevention of dental caries. Cochrane Database Syst Rev 2009(3):CD007819.

179. Ligtenberg AJM, Veerman ECI, Amerongen AVN, Mollenhauer J. Salivary agglutinin/glycoprotein-340/ DMBT1: a single molecule with variable composition and with different functions in infection, inflammation and cancer. Biological Chemistry 2007;388(12):1275-89.
180. Skinner AL, Laurence JS. High-field solution NMR spectroscopy as a tool for assessing protein interactions with small molecule ligands. J Pharm Sci 2008;97(11):4670-95.

181. Thomas JG, Nakaishi LA. Managing the complexity of a dynamic biofilm. Journal of the American Dental Association 2006;137:10S-15S.

182. Breschi L, Mazzoni A, Ruggeri A, Cadenaro M, Di Lenarda R, De Stefano Dorigo E. Dental adhesion review: aging and stability of the bonded interface. Dent Mater 2008;24(1):90101.

183. Ferracane JL. Hygroscopic and hydrolytic effects in dental polymer networks. Dent Mater 2006;22(3):211-22.

184. Harnirattisai C, Inokoshi S, Hosoda H, Shimade Y. Interfacial Morphology of an Adhesive Composite Resin and Etched Caries-Affected Dentin. Oper Dent 1992;17:222-8.

185. Nakajima M, Sano H, Burrow MF, Tagami J, Yoshiyama M, Ebisu S, Ciucchi B, Russell CM, Pashley DH. Tensile bond strength and SEM evaluation of caries-affected dentin using dentin adhesives. J. Dent. Res. 1995;74:1679-88.

186. Yoshiyama M, Carvalho RM, Sano H, Horner JA, Brewer $\mathrm{PD}$, Pashley DH. Regional bond strengths of resins to human root dentine. Journal of Dentistry 1996;24(6):435-42.

187. Yoshiyama M, Urayama A, Kimochi T, Matsuo T, Pashley DH. Comparison of Conventional vs Self-Etching Adhesive Bonds to Caries-Affected Dentin. Oper Dent 2000;25:163-9.

188. Drummond JL. Degradation, fatigue, and failure of resin dental composite materials. J Dent Res 2008;87(8):710-9.

Received: 27/08/2012

Accepted: 27/08/2012

Corresponding author: Paulette Spencer, PhD, DDS.

Address: 1530 W.15th St, Lawrence, Kansas 66045 Email: pspencer@ku.edu 